\title{
Two new species of Morinda (Rubiaceae) from Sumatra and Borneo
}

\author{
Suratman ${ }^{1}$
}

Key words

Borneo

Morinda

new species

Rubiaceae

Sumatra
Abstract Two new species of Morinda from Sumatra and Borneo, M. lanuginosa and M. wongiana, are described and illustrated. The morphological comparison of the new taxa with similar species in the genus is also discussed.

Published on 11 March 2011

\section{INTRODUCTION}

Morinda L. is one of the 611 genera belonging to family Rubiaceae Juss. (Govaerts et al. 2009). The genus consists of c. 90 species (Mabberley 2008), and is distributed widely in the tropics and subtropics, but absent from Northern and Southern Africa, the Mediterranean region, Arabian Peninsula, Western Asia, New Zealand and Southern South America (Govaerts et al. 2009).

The presence of raphide idioblasts, valvate corolla aestivation and often heterostylous flowers points to a position within subfamily Rubioideae (Robbrecht \& Manen 2006). It has been grouped in the tribe Morindeae together with Appunia Hook.f., Coelospermum Blume, Gynochthodes Blume, Pogonolobus F.Muell. and Syphonandrium K.Schum. (Razafimandimbison et al. 2008). Igersheim \& Robbrecht (1993) discussed the circumscription of the Morindeae and proposed to restrict the tribe to representatives with a "bicarpellate gynoecium comprised of a common style with two stigma lobes, and two biovulate locules". Razafimandimbison et al. (2009) considered that within the tribe Morindeae, the type genus Morinda is traditionally and currently circumscribed based on its head inflorescences and syncarpous fruits. These characters are also present in other Rubiaceae genera, especially Schradera, which can look similar to Morinda.

In the fruiting stage, Schradera resembles Morinda but can be distinguished by not having true syncarps. The fruiting heads of Morinda consist of fused fruitlets whereas the fruitlets of Schradera are not fused. In head inflorescence, ovaries of neighbouring flowers in Morinda are united or at least closely pressed together whereas ovaries of adjacent flowers of Schradera in close contact with each other but not fused (Puff 2007).

During the preparation of a treatment of the genus Morinda in Sumatra and Borneo, several Morinda collections could not be identified and represent two new species, which are described and illustrated here.

\footnotetext{
Post Graduate School, Bogor Agricultural University, Bogor, West Java, Indonesia. Current address: Department of Biology, Faculty of Mathematics and Natural Sciences, Sebelas Maret University (UNS), Solo, Central Java, Indonesia; e-mail: suratmanmipauns@yahoo.com.
}

\section{DESCRIPTIONS}

\section{Morinda lanuginosa Suratman, sp. nov. - Fig. 1}

Scandens. Ramuli glabri. Stipulae margine leviter connatae prope basin vel truncatam unitae, glabrae. Petioli glabri. Folia elliptica vel oblonga vel elliptica ad oblonga vel raro lanceolata, (0.9-)4-11.1 cm longa, $(0.45-) 1.2-4.1 \mathrm{~cm}$ lata, glabra, coriacea; nervis secundariis $(5-) 6-8$ paribus, glabris; domatia absentia. Capitula florifera mascula terminalia, pseudo-umbellata, 2-6 fasciculata, circa 8-18 flora, 3-5.5 mm longa et 2-5.5 mm lata (sine corollae). Peduncula glabra. Flos masculus $4-5$ partitus; calyx limbus tubularis, 1-1.5 mm longus, 1-2 mm latus, truncatus, glabrus; calyx lobus nullus; corolla tubus $2-7 \mathrm{~mm}$ longus, $0.5-1.5 \mathrm{~mm}$ latus, intus lanuginosus, extus glabrus; corolla faucus intus lanuginosus, extus glabrus; corolla lobus glabrus; antherae linear vel linear-lanceolata. Flos hermaphroditus et femineus ignotus. Capitula fructiferus et seminibus ignotus. - Typus: P. Buwalda 6744 (holo BO; iso A, K, L, PNH n.v., SING), Indonesia, Indragiri Uplands, Kuala Belilas, 28 April 1939.

Etymology. The specific epithet for this species is derived from the latin word lanuginosus, which means woolly, in reference to the dense woolly hairs along the inner surface of the corolla tube of the species.

Climber. Branchlets divaricating, subquadrangular when young but becoming terete or subterete with age, bark smooth but usually slightly sulcate on young branchlets, all parts glabrous, not glossy, grey or dark brown or dark brown to black brownish coloured when dry; internodes (5-) $9-59$ by $0.5-4 \mathrm{~mm}$. Stipules triangular, $0.5-6$ by $2-5 \mathrm{~mm}$, shortly connate to connate above axils, glabrous, apex obtuse or subacute or truncate, subchartaceous to membranous, vein indistinct to slightly raised on both sides. Leaves petioles subquadrangular or subterete or subtriangular, $6-25$ by $0.5-1.5 \mathrm{~mm}$, grooved or flattened along upper part, smooth or slightly sulcate, glabrous; lamina elliptic or oblong or elliptic to oblong or rarely lanceolate, (0.9-)4-11.1 by $(0.45-) 1.2-4.1 \mathrm{~cm}$, base cuneate or obtuse, margin entire and glabrous, apex cuspidate or acuminate or acute or obtuse or nearly rounded, glabrous on both sides, coriaceous when dry, drying light to medium brown below and dark greyish brown to light grey above; secondary veins (5-)6-8 pairs, indistinct to prominently raised below and flat to moderately raised above, glabrous; midrib raised prominently below and flat to slightly raised above, glabrous, smooth or usually slightly sulcate; tertiary veins indistinct to slightly raised on both sides, glabrous; domatia absent. Male flowering heads terminal, arranged in pseudo-umbels, consisting of 2-6 heads, each head with 


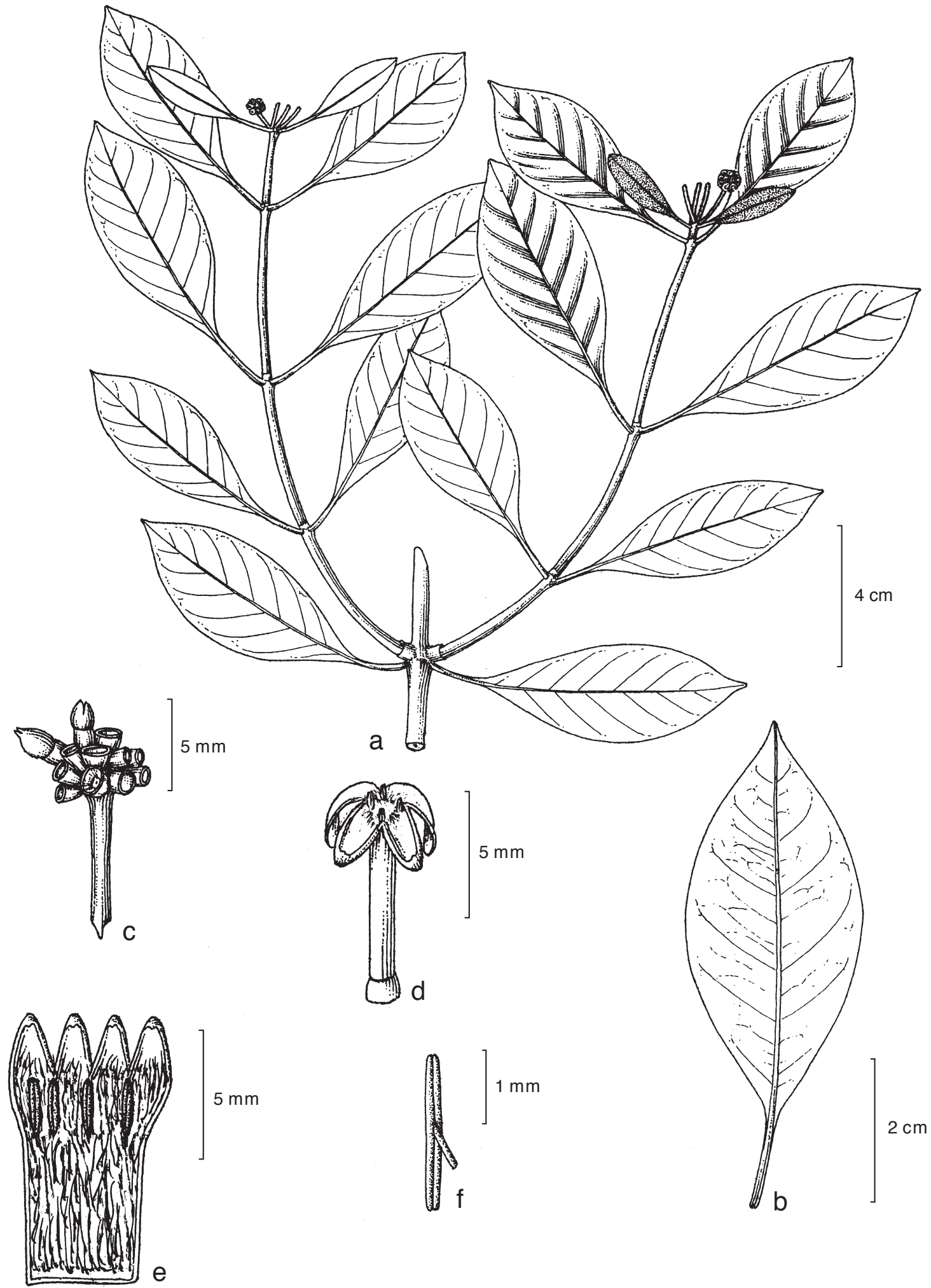

Fig. 1 Morinda lanuginosa Suratman. a. Branch habit; b. lower leaf surface showing venation (note that domatia are absent in the axils of secondary veins); c. flowering head with flower buds; $d$. mature open male flower; e. longitudinal section of inner surface of flower showing woolly hairs; f. dorsifixed stamen (a-c: P. Buwalda 6744; d-f: Berkhout 1507).

c. $8-18$ flowers, $3-5.5$ by $2-5.5 \mathrm{~mm}$ (without the corollas); peduncles subquadrangular or subterete, $3-18$ by $0.5-1 \mathrm{~mm}$, glabrous, smooth or slightly sulcate. Male flowers 4-5-merous, $2-10.5$ by $(0.5-) 0.75-2 \mathrm{~mm}$, green coloured when still in bud; calyx limb tubular, $1-1.5$ by $1-2 \mathrm{~mm}$, truncate, glabrous; calyx lobe none; adjacent calyx tubes fused with each other; corolla tube $2-7$ by $0.5-1.5 \mathrm{~mm}$, lanuginose along inside but glabrous outside; corolla throat lanuginose inside but glabrous outside; corolla lobes $4-5$, oblong or elliptic to oblong, $2-4$ by $0.75-2$ $\mathrm{mm}$, apex acute or obtuse, valvate in bud and thickened at margins, glabrous on both sides; stamens $4-5$; anthers linear or linear-lanceolate, $1.75-2.75$ by c. $0.1-0.3 \mathrm{~mm}$, dorsifixed around the middle or below the middle of filaments, only the tips exserted from the throat; filaments thin, $0.25-1$ by c. $0.1-$ $0.25 \mathrm{~mm}$; gynoecium completely undeveloped; stigma and rudimentary style none; disk present, located on the roof of the rudimentary ovary; rudimentary ovaries of adjacent flowers fused with each other, reduced and empty. Bisexual and female flowers unknown. Bracts and bracteoles none. Fruits and seeds unknown. 
Distribution - Sumatra (Bangka Island and Kuala Belilas).

Habitat \& Ecology — Found in primary forest, somewhat swampy.

Vernacular names - Akar padang (Bangka); akar seminyak (Kuala Belilas).

Additional specimens studied. INDONEsIA, Bangka Belitung, Bangka, Pangkal Pinang, Teysmann 18351 (BO); Bangka, unknown locality, 22 Sept. 1906, Berkhout 1507 (BO).

Note - Morinda umbellata L. is a complex species with a number of described subspecies and varieties (Govaerts et al.
2009). I have chosen the specimens from Sumatra usually identified as $M$. umbellata (but possibly not identical to that species, Ridsdale 1998) as basis for comparison to diagnose $M$. lanuginosa. Morinda lanuginosa is similar to these specimens in habit and inflorescence shape but can be distinguished by the absence of domatia and the corolla tube considerably longer (2-7 $\mathrm{mm}$ long) in mature open male flower than in the specimens usually identified as $M$. umbellata $(0.25-1.5$ $\mathrm{mm}$ long). Morinda lanuginosa also somewhat resembles $M$. wongiana in habit, inflorescence form and leaf texture but can be distinguished by its tubular calyx limb in male flowers

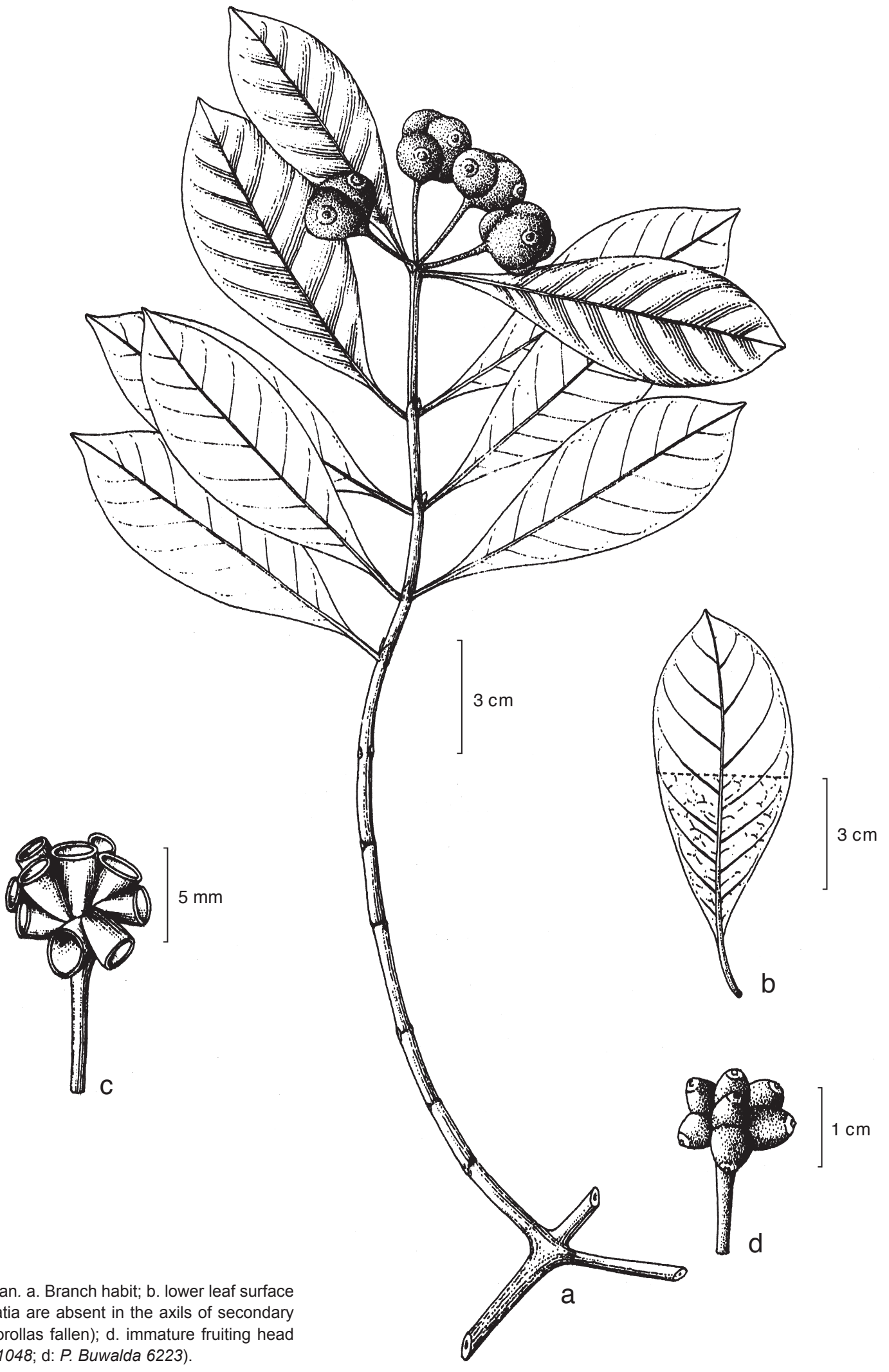

Fig. 2 Morinda wongiana Suratman. a. Branch habit; b. lower leaf surface showing venation (note that domatia are absent in the axils of secondary veins); c. male flowering head (corollas fallen); d. immature fruiting head (a, b: H.F. Sun 9937; c: H. Hallier 1048; d: P. Buwalda 6223). 
which is considerably shorter (1-1.5 mm long vs (1.75-)2-3.5 $\mathrm{mm}$ long). Only three herbarium specimens are known and all show male flowers. This species requires further field investigation and more material is needed to clarify its floral morphology, especially of the bisexual and female flower.

\section{Morinda wongiana Suratman, sp. nov. - Fig. 2}

Frutex (?). Ramuli glabri. Stipulae margine leviter connatae prope basin, glabrae. Petioli glabri. Folia obovato-oblonga vel elliptica vel oblonga, (3.5-) $3.7-9.5(-10) \mathrm{cm}$ longa, $1.6-4.1 \mathrm{~cm}$ lata, glabra, coriacea; nervis secundariis 6-8 paribus, glabris; domatia absentia. Capitula florifera mascula terminalia, pseudo-umbellata, (2-)3-6(-7) fasciculata, circa (4-)5-10 flora, (3-)4-7.7 $\mathrm{mm}$ longa, (5-)5.1-8.2 mm lata (sine corollae). Flos masculus calyx limbus subcampanulatus, (1.75-)2-3.5 mm longus, (1.5-)2-3 mm latus, vertice truncatus, glabrus; calyx lobus nullus. Flos hermaphroditus et femineus ignotus. Capitula fructifera globosa vel subglobosa, 5-17(-20) $\mathrm{mm}$ longa, 5-17(-20) mm lata, glabra. Pedunculis (6-)7.25-24 mm longis, glabris. - Typus: H.F. Sun 9937 (holo BO), Indonesia, Sumatra, Baturadja.

Etymology. The specific epithet honours Prof. Dr. K.M. Wong, a botanist from the University of Malaya (Malaysia), who revised Morinda in the Malay Peninsula.

Shrub(?, see note). Branchlets divaricating, subquadrangular when young but becoming terete with age, bark smooth on young branchlets, all parts glabrous, not glossy, light brown to dark greyish or dark brown to black when dry; internodes $17-40(-78)$ by $1.25-4 \mathrm{~mm}$. Stipules triangular or broadly triangular, (4-)5-7 by 3-7 $\mathrm{mm}$, shortly connate above axils, glabrous on both sides, apex acute or subacute to obtuse, membranous or subchartaceous, veins indistinct to slightly raised. Leaves petioles subterete or subquadrangular, (5-)7-12(-16) by $0.5-1(-1.5) \mathrm{mm}$, grooved or flattened at upper part, sulcate, glabrous on all parts; lamina obovate-oblong or elliptic or oblong, (3.5-)3.7-9.5(-10) by $1.6-4.1 \mathrm{~cm}$, base cuneate, margin entire and glabrous, apex shortly acuminate or shortly cuspidate, glabrous on both sides, coriaceous when dry, drying dark brown below and dark brown to light greyish brown above; secondary veins 6-8 pairs, raised prominently below and flat to slightly to prominently raised above, glabrous; midrib raised prominently below and flat to slightly raised above, glabrous, smooth or usually slightly sulcate; tertiary veins slightly raised to almost indistinct on both sides, glabrous; domatia absent. Male flowering heads terminal, arranged in pseudo-umbels, consisting of $(2-) 3-6(-7)$ heads, each head with c. (4-)5-10 flowers, (3-)4-7.7 by (5-)5.1-8.2 $\mathrm{mm}$ (without the corollas); peduncles terete or subterete, $6-7.25$ by $0.75-1(-1.5) \mathrm{mm}$, glabrous, smooth or slightly sulcate. Male flowers calyx limb subcampanulate, (1.75-)2-3.5 by (1.5-)2-3 mm, truncate, glabrous, red coloured; calyx lobes indistinct, adjacent calyx tubes fused with each other; corollas not seen; stamens not seen; gynoecium completely undeveloped; stigma and rudimentary style none; disk present, located on the roof of the rudimentary ovary; rudimentary ovaries of adjacent flowers fused with each other, reduced and empty. Bisexual and female flowers unknown. Bracts lacking. Bracteoles none. Fruits fruiting heads globose or subglobose, $5-17(-20)$ by $5-17(-20) \mathrm{mm}$, glabrous, with 4-7 fused fruitlets; stalks subterete, (6-)7.25-24 by $1-2 \mathrm{~mm}$, glabrous, sulcate. Seeds not seen.

Distribution - Sumatra and Borneo (Kalimantan).

Habitat \& Ecology - Found in rain forest and secondary vegetation, a few metres above sea level.

Additional specimens studied. INDONESIA, Riau Archipelago, Sambu Island, Dec. 1938, P. Buwalda 6223 (BO); West Kalimantan, Soengei Sambas, 1893-1894, H. Hallier 1048 (BO); Kalimantan, without locality, 1896-1897, Jaheri 1893 (BO).
Note - On Buwalda's labels, this is noted as shrub. A morphological comparison of this plant with related species however shows that most characters match with those of climbing species. This species is similar to $M$. rigida Miq. leaf texture and inflorescence shape but can be distinguished from the latter because the surface of young branchlets, leaves, midribs, petioles, peduncle, outer calyx limb surface of male flowers and fruiting head stalks is always glabrous. The calyx limb and fruiting head stalks are also considerably longer ((1.75-)2-3.5 $\mathrm{mm}$ resp. (6-)7.25-24 $\mathrm{mm}$ ) than in $M$. rigida $(0.75-1.5 \mathrm{~mm}$ resp. 3-6 mm). Only four specimens are known in this study, one with fallen corollas $(H$. Hallier 1048), two with mature fruit (H.F. Sun 9937 and Jaheri 1893) and one with immature fruit (P.Buwalda 6223). The distinction of the floral types is not always easy, especially for the inexperienced. Therefore, more material is needed to clarify floral morphology of this species.

Acknowledgements I would like to express my gratitude to my supervisors, Dr. Sri Sudarmiyati Tjitrosoedirdjo (Bogor Agricultural University) and Dr. Johanis Palar Mogea (Herbarium Bogoriense, Research Centre for BiologyIndonesian Institute of Sciences) for their advice and guidance throughout the study. I would like to thank the Keeper of Herbarium Bogoriense (BO) who gave the opportunity and facilities to study specimens. I acknowledge gratefully the financial support for my study and work from BPPS (Beasiswa Program Pasca Sarjana), General Directorate of Higher Education, Ministry of National Education, Republic of Indonesia. Especially, I would like to thank Prof. Dr. Khoon Meng Wong (University of Malaya, Malaysia) and Prof. Dr. Mien A. Rifai (BO) for a critical reading of the manuscript. I am also grateful to Dr. Jan Thomas Johansson (Department of Botany, University of Stockholm, Sweden) who was so kind to provide some important literatures.

\section{REFERENCES}

Govaerts R, Ruhsam M, Andersson L, Robbrecht E, Bridson D, Davis A, Schanzer I, Sonké B. 2009. World checklist of Rubiaceae. http://www.kew. org/wcsp/rubiaceae. Last accessed 8 September 2009.

Igersheim A, Robbrecht E. 1993. The character states and relationships of the Prismatomerideae (Rubiaceae-Rubioideae). Comparisons with Morinda and comments on the circumscription of the Morindeae s.str. Opera Botanica Belgica 6: 61-79.

Mabberley DJ. 2008. The plant-book. A portable dictionary of the vascular plants. Edition 3. Cambridge University Press, Cambridge.

Puff C. 2007. Keys to genera of Thai Rubiaceae. http://homepage.univie. ac.at/ puffc9/FTH-RUB/FTH-RUB_HOME.htm. Last accessed 8 September 2009.

Razafimandimbison SG, McDowell TD, Halford DA, Bremer B. 2008. Paraphyly of the pantropical genus Morinda and its taxonomic implications. In: Ochoterena H, Terrazas T, De Block P, Dessein S (eds), IV International Rubiaceae (Gentianales) Conference - Programme \& Abstracts. Scripta Botanica Belgica 44: 58.

Razafimandimbison SG, McDowell TD, Halford DA, Bremer B. 2009. Molecular phylogenetics and generic assessment in the tribe Morindeae (Rubiaceae-Rubioideae): how to circumscribe Morinda L. to be monophyletic? Molecular Phylogenetics and Evolution 52, 3: 879-886.

Ridsdale CE. 1998. Morinda L. In: Dassanayake MD, Clayton WB (eds), A Revised Handbook to the Flora of Ceylon 12: 320-324. Balkema Publishers, Rotterdam.

Robbrecht E, Manen J-F. 2006. The major evolutionary lineages of the coffee family (Rubiaceae, angiosperms). Combined analysis (nDNA and cpDNA) to infer the position of Coptosapelta and Luculia, and supertree construction based on rbcL, rps16, trnL-trnF and atpB-rbcL data. A new classification in two subfamilies, Cinchonoideae and Rubioideae. Systematics and Geography of Plants 76: 85-145. 